\title{
Japanese clematis, Clematis terniflora (D.C.) Ranunculaceae 1
}

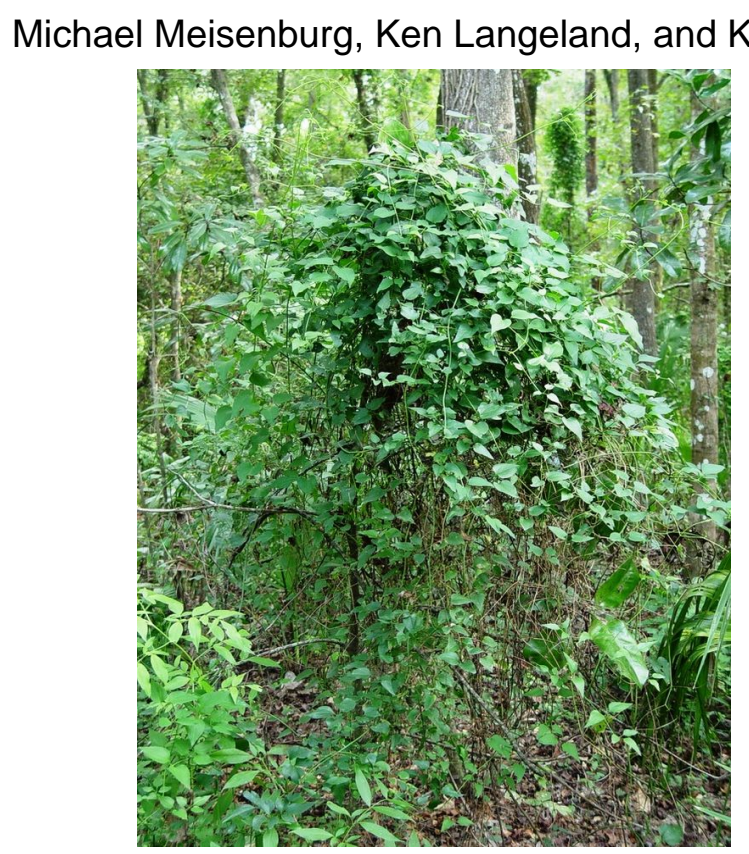

Figure 1. A Japanese clematis has smothered a Southern magnolia in a natural, wooded area of Gainesville, FL.

\section{Introduction}

Japanese clematis (Clematis terniflora) is a vigorous woody vine that has been used for landscaping in the southeastern United States since 1877. The plant is recommended for landscape use in cold-hardy zones and is sometimes grown on trellises. \\ UF}


clematis are entirely smooth, without teeth. However, leaves of the small plants may have teeth, which are sometimes rounded (Figure 3). Leaves on small plants are often variegated (Figure 3).

Vines usually grow to about $1 / 2$-inch in diameter (rarely to 4 inches). The vine can climb up to 30 feet with the aid leaf petioles twisting around supports (Figure 4). The bark is light brown with long splits and long shredding strips. Like other Clematis species, nodes persist on stems every 6 - 8 inches from where the leaves attach (Figure 5). Sporadic flowering takes place year-round, but occurs primarily in the late summer and early fall. Densely pubescent, star-shaped flowers are white with four sepals about 1 1/4 inch in length (Figure 6). Seeds are small and brown with a white, feathery plume (Figure 7). Mature seeds can germinate anywhere between one and nine months after maturity. Vines trailing along the surface of the ground rarely take root.

Two native species of similar-looking Clematis also occur throughout northern and central Florida: virginsbower (C. virginiana) and satincurls $(C$. catesbyana). Toothed leaves distinguish each of these native species from Japanese clematis (Figure 8).

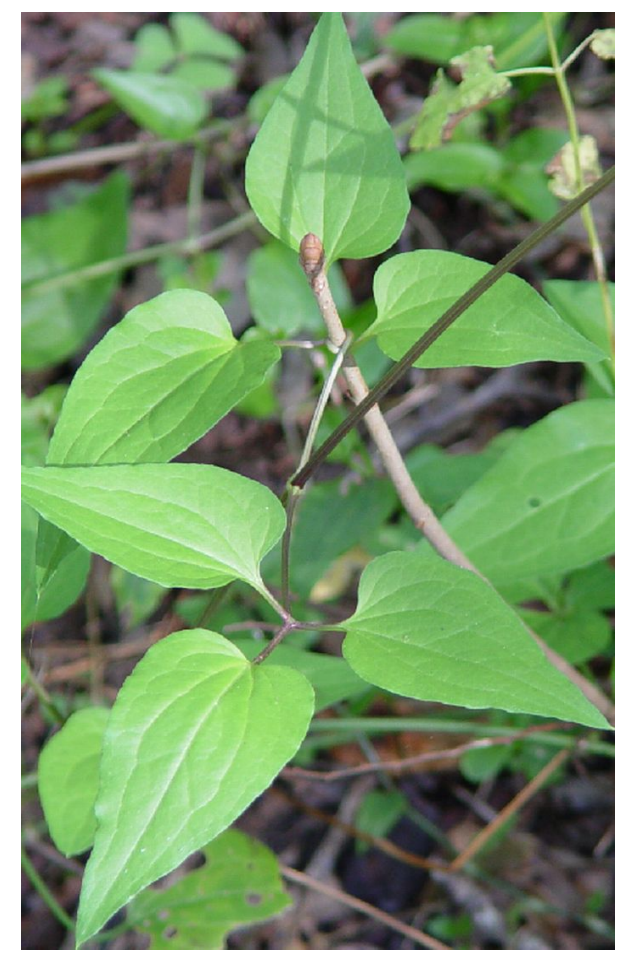

Figure 2. Leaves of the invasive Japanese clematis usually have entire margins (smooth edges with no serrations).

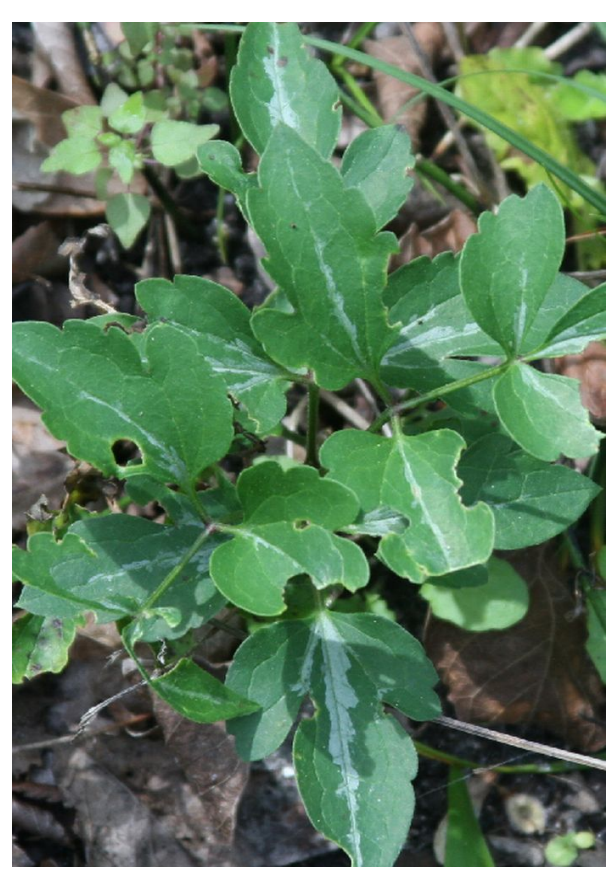

Figure 3. Japanese clematis leaves can have some teeth along the margins and light green down the middle.

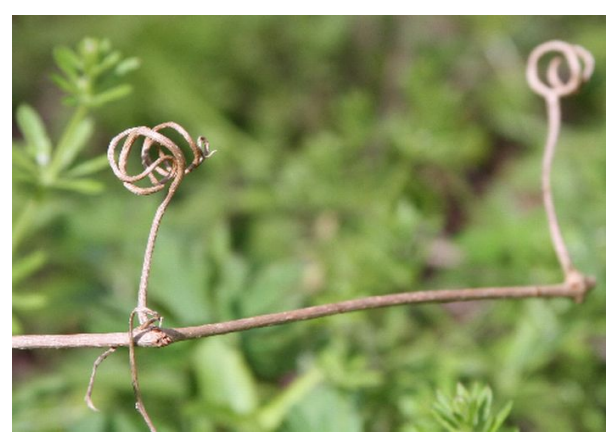

Figure 4. Leaf petioles wrap around vegetation to support climbing vines.

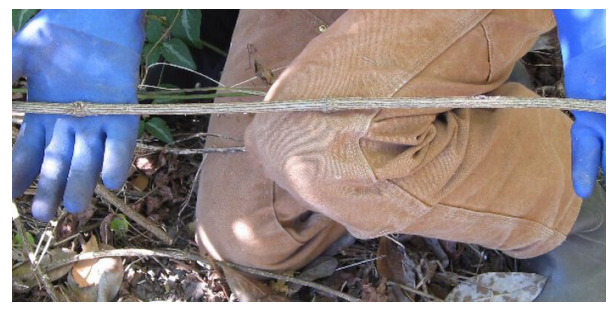

Figure 5. Clematis stems are distinctive with their swelled nodes every 6-8 inches.

\section{Impacts}

Populations of Japanese clematis have been occurring with increased frequency in northern Florida. This invasive plant is a prolific seed producer, and the short-winged appendages and fairly large seed mean most seeds are probably not dispersed far. While this method of dispersal may limit the speed at which the population expands, the 


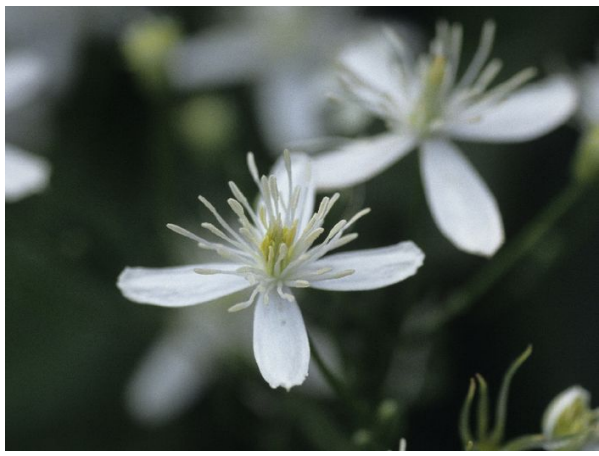

Figure 6. Flowers of Japanese clematis.

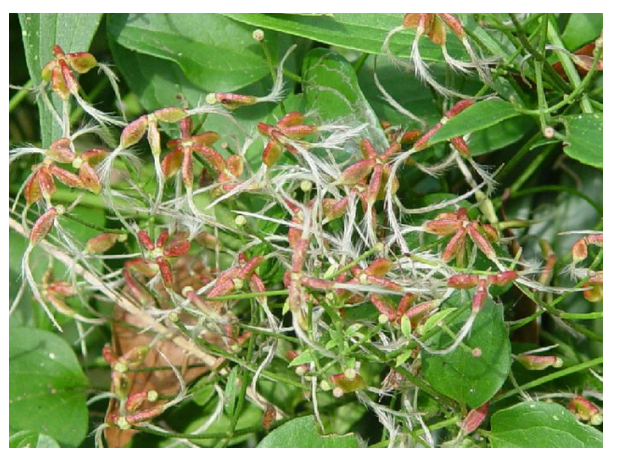

Figure 7. A cluster of Japanese clematis seeds. These seeds are not quite mature as evidenced by their light color.

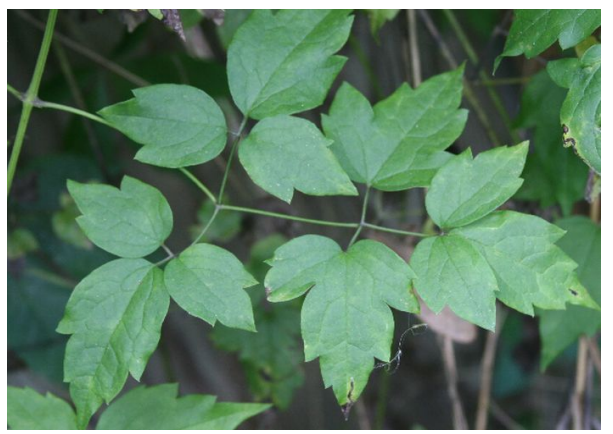

Figure 8. The toothed leaves of native Clematis (such as these $C$. catesbyana) aid in distinguishing them from the invasive $C$. terniflora.

plant occurs at high densities within infested areas. In natural wooded areas, Japanese clematis commonly overgrows saplings and small trees, killing some. (See Figure 1.) As the Japanese clematis vine climbs, it has the potential to smother fully grown trees. In a review of Japanese clematis by UF/IFAS'

Assessment of Non-native Plants in Florida's Natural Areas (http://plants.ifas.ufl.edu/assessment/), a lack of sufficient evidence for the invasiveness of the plant in northern and central Florida resulted in Japanese clematis being listed as "OK" for planting throughout Florida.
By contrast, Japanese clematis is considered invasive by exotic/invasive plant councils in Alabama, Georgia, Tennessee, South Carolina, and the Mid-Atlantic, as well as in Florida. Given the invasive designation these councils have assigned to Japanese clematis, and considering, as well, the plant's tendency to escape cultivation and invade intact natural areas, it would be prudent not to cultivate this plant in Florida

\section{Management}

Preventative. Japanese clematis is still at the stage where it can be effectively managed by preventing its introduction into new areas. Homeowners should not introduce this plant to their lawns or gardens, but instead plant the native $C$. virginiana or catesbyana if so desired. Identification of Japanese clematis is important to distinguish it from the native Clematis. Homeowners wishing to remove Japanese clematis vines from their property should properly dispose of cuttings and seeds, leaving them out of mulch and yard waste. Japanese clematis will probably continue to spread in natural areas throughout the Southeast. Natural-area managers should be proficient in identifying the species and be vigilant for its occurrence.

Mechanical. Seedlings may be hand-pulled or mowed. Mature plants can be cut by hand or mowed. Plants must be cut back enough and dug up to ensure complete removal.

Biological. To date no biological control exists for this species. However, leaf damange is occasionally observed (Figure 2) perhaps because Japanese clematis shares its range with several native Clematis.

Chemical. Current chemical-control methods include foliar applications of triclopyr amine (e.g. 2-3\% Garlon 3A) and triclopyr ester (e.g. 15\% Garlon 4 oil) for basal-bark applications. Either formulation, applied to cut stump, is effective in controlling the plant. Foliar application of glyphosate (e.g. 3\% Roundup ) provides good, but short-term control. For basal-bark applications, be sure to locate where the vine is rooted. Clematis vines will sometimes grow up one tree, trail back down to the ground, and climb up another tree. Applying 
herbicide to a trailing vine will only kill the distal part; another treatment will later be required.

\section{References and Useful Links}

Clematis terniflora. Kemper Center for Home Gardening, Missouri Botanical Gardens.

http://www.mobot.org/gardeninghelp/plantfinder/

Plant.asp?cpde $=\mathrm{A} 300$

Clematis terniflora Fact Sheet.

http://www.cnr.vt.edu/dendro/dendrology/syllabus2/

factsheet.cfm?ID=494

Clematis terniflora: Sweet Autumn Clematis

http://www.plantoftheweek.org/week273.shtml

Clematis terniflora. Global Invasive Species

Database.

http://www.invasivespecies.net/database/species/

ecology.asp?si=1224\&fr=1\&sts

Floridata:

http://www.floridata.com/ref/c/clem_ter.cfm

Invasive Plant List: Planting for a Livable

Delaware.

http://dda.delaware.gov/publications/plant_industries/

DEInvasPlntBklt.pdf 